University of New Hampshire

University of New Hampshire Scholars' Repository

Communication Scholarship

Communication

2008

\title{
The Rhetoric(s) of St. Augustine's Confessions
}

James M. Farrell

University of New Hampshire, jmf@unh.edu

Follow this and additional works at: https://scholars.unh.edu/comm_facpub

Part of the Christianity Commons, Classical Literature and Philology Commons, Ethics in Religion Commons, History of Christianity Commons, Medieval History Commons, Medieval Studies Commons, and the Rhetoric Commons

\section{Recommended Citation}

James M. Farrell, "The Rhetoric(s) of St. Augustine's Confessions," Augustinian Studies 39:2 (2008), 265-291.

This Article is brought to you for free and open access by the Communication at University of New Hampshire Scholars' Repository. It has been accepted for inclusion in Communication Scholarship by an authorized administrator of University of New Hampshire Scholars' Repository. For more information, please contact Scholarly.Communication@unh.edu. 


\section{The Rhetoric(s) of St. Augustine's Confessions.}

\section{James M. Farrell University of New Hampshire}

Much of the scholarship on Augustine's Confessions has consigned the discipline of rhetoric to the margins. Rhetoric was Augustine's "major" in school, and his bread and bacon as a young adult. But in turning to God in the garden at Milan, Augustine also turned away from his profession. Rightly so, the accomplishment of Augustine's conversion is viewed as a positive development. But the conversion story also structures the whole narrative of the Confessions and thus rhetoric is implicated in that narrative. It is the story of "Latin rhetorician turned Christian bishop." ${ }^{\text {Augustine's }}$ intellectual and disciplinary evolution is mapped over a story of spiritual ascent. As James J. Murphy has written, "Augustine himself, in a certain sense, was converted from rhetoric to Christianity." ${ }^{2}$ As a result, Augustine's denunciation of his rhetorical past at the climax of his autobiographical account is seen as a parallel to his denial of worldly desires and pleasures of the flesh, and this is a reading Augustine encourages. He sees the departure from rhetoric as an emancipation, praising God, and "full of joy," that his "release from the profession of rhetoric was to become a reality, just as in my mind, I was free from it already." ${ }^{3}$ Read against the narrative of his conversion, then, rhetoric was doomed.

\footnotetext{
${ }^{1}$ Albert C. Outler, "Augustine and the Transvaluation of the Classical Tradition," The Classical Journal 54 (1959), 213.

2 James J. Murphy, Rhetoric in the Middle Ages: A History of Rhetorical Theory from St. Augustine to the Renaissance (Berkeley: University of California Press, 1974), 51. See also Nello Cipriani, "Rhetoric," in Allan D. Fitzgerald, ed., Augustine Through the Ages: An Encyclopedia (Grand Rapids, MI: Will B. Eerdmans, 1999), 724.

${ }^{3}$ Saint Augustine, Confessions, trans. R. S. Pine-Coffin (New York: Penguin, 1984), IX.4.7 (et venit dies quo etiam actu solverer a professione rhetorica, unde iam cogitatu solutus eram, et factum est).
} 
The narrative marginalization of rhetoric within the Confessions in part explains the insufficient scholarly attention given to the range of connections between Augustine's spiritual autobiography and his former professional discipline. In this essay, I want to offer a sympathetic reading of the rhetoric(s) of Augustine's Confessions. First, as a historian of rhetoric I am interested in what Augustine's narrative can tell us about the theory and practice of rhetoric in the late classical period and the early Christian era. From this perspective, I am interested in exploring what Augustine discloses about the rhetoric he learned in the provincial Roman schools, and taught at Carthage, Rome, and Milan. Second, I am interested in Augustine's own work on rhetoric, especially his De Doctrina Christiana, most of which he composed during the period right before he began the Confessions. In particular, I am interested in how the rhetorical ethics that emerges from Augustine's formal treatment of Biblical exegesis and preaching, and which distinguishes Augustine's rhetoric from that of his classical predecessors, can illuminate our interpretation of the Confessions. Finally, I am interested in exploring how the Confessions itself works as a rhetorical text - that is, as a discourse addressed to an audience for the purpose of influence. In particular, I am interested in exploring the specific pastoral functions served by Augustine's narrative.

\section{The Rhetoric Augustine Learned and Taught}

As a boy, Augustine partook of a "common system of education through rhetoric."4 The Imperial rhetoric schools of the fourth century were, in his own words, places "where men are made masters of words," and "learn the art of persuasion."

\footnotetext{
${ }^{4}$ Charles Sears Baldwin, Medieval Rhetoric and Poetic (to 1400) (Gloucester, MA: Peter Smith, 1959), viii.

${ }^{5}$ Confessions I.16.26 (hinc verba discuntur, hinc adquiritur eloquentia, rebus persuadendis sententiisque explicandis maxime necessaria).
} 
That art was learned by means of a curriculum that was standard in "countless provincial schools" ${ }^{16}$ and which served as "an instrument of acculturation and cultural cohesion." As Thomas Conley explains, the study of rhetoric in particular "was important training for administrators of imperial policies in an empire of vast proportions," and "enabled a successful student to enter public life in one of the many municipal assemblies that were active in the provinces." ${ }^{7}$

No doubt this was the purpose of education expressed to Augustine by his schoolmasters, and even by his parents. "Their only concern," he wrote, "was that I should learn to make a good speech, and how to persuade others by my words." ${ }^{18}$ As Augustine understood, it was his way to "get on in the world," to "gain the respect of others" and to earn "what passes for wealth in this world." Looking back on his earliest days in school he saw he was being prepared "to play a less creditable game later in life."10 At the time, however, "it was my ambition to be a good speaker," ${ }^{11}$ and he enjoyed being "at the top of the school of rhetoric." ${ }^{12}$

Part of his rhetorical training consisted of practice in declamation, "the preparation and delivery of fictitious speeches." ${ }^{13}$ In such exercises, "a theme is proposed by the teacher, and the student of rhetoric composes and delivers a speech

${ }_{7}^{6}$ Murphy, Rhetoric in the Middle Ages, 26.

${ }^{7}$ Thomas M. Conley, Rhetoric in the European Tradition (New York: Longman, 1990), 62, 60. See also Luigi F. Pizzolato, Capitoli di retorica agostiniana (Rome: Istituto Patristico Augstinianum, 1994), 7-27. ${ }^{8}$ Confessions 11.2 .4 (sed cura fuit tantum ut discerem sermonem facere quam optimum et persuadere dictione).

${ }^{9}$ Confessions 1.9 .14 (quandoquidem recte mihi vivere puero id proponebatur, obtemperare monentibus, ut in hoc saeculo florerem et excellerem linguosis artibus ad honorem hominum et falsas divitias famulantibus. inde in scholam datus sum ut discerem litteras, in quibus quid utilitatis esset ignorabam miser).

${ }^{10}$ Confessions 1.9 .15 (quia ludebam pila puer et eo ludo impediebar quominus celeriter discerem litteras, quibus maior deformius luderem).

${ }_{11}$ Confessions III.4.7 (discebam libros eloquentiae, in qua eminere cupiebam).

${ }_{12}^{12}$ Confessions III.3.6 (et maior etiam eram in schola rhetoris, et gaudebam superbe et tumebam typho)

${ }^{13}$ Murphy, Rhetoric in the Middle Ages, 38. 
on that theme." ${ }^{14}$ We know that Augustine participated in these "imaginary contests of the schoolroom" ${ }^{15}$ because he recalls he had some success in the "tournaments"16 in which he competed. On one such occasion, "the contest was to be won by the boy who found the best words to suit the meaning and best expressed feelings of sorrow and anger appropriate to the majesty of the character he impersonated. ${ }^{17}$ By his speaking, he "won praise from the people whose favour I sought,"18 and "for this reason I was called a promising boy. ${ }^{19}$ These competitive declamations remained a part of Augustine's training everywhere he studied. He writes of his days amidst the "hissing cauldron of lust"20 at Carthage where he sought to put "an edge on my tongue," ${ }^{11}$ and "hunt for worthless popular distinctions, the applause of an audience, prizes for poetry, or quickly fading wreaths won in competition."22

Augustine is describing a rhetorical education typical of the Second Sophistic. During this period (50 to 400 A.D.) the full system of classical rhetorical theory was reduced in practice to an emphasis on style and delivery. It was a "period of oratorical excess" $^{\prime 23}$ in which rhetoric became largely "an art of display" and an "oratory of

\footnotetext{
${ }^{14}$ George A. Kennedy, Classical Rhetoric in its Christian and Secular Traditions from Ancient to Modern Times (Chapel Hill: University of North Carolina Press, 1980), 37.

${ }^{15}$ James J. Murphy, "The End of the Ancient World: The Second Sophistic and Saint Augustine," in A Synoptic History of Classical Rhetoric, ed. James J. Murphy (Davis, CA: Hermagoras Press, 1983), 179. See also Henri-Irénée Marrou, Saint Augustin et la Fin de la Culture Antique (Paris: Editions E. De Boccard, 1958), 50-54; Joseph Finaert, Saint Augustin Rhéteur (Paris: Société D'édition "Les Belles Lettres," 1939), 2.

${ }^{16}$ Confessions I.19.30 (et huius harenae palaestra erat illa).

${ }^{17}$ Confessions I.17.27 (et ille dicebat laudabilius in quo pro dignitate adumbratae personae irae ac doloris similior affectus eminebat, verbis sententias congruenter vestientibus).

${ }_{18}^{18}$ Confessions 1.19 .30 (in quibus laudabar ab eis quibus placere tunc mihi erat honeste vivere).

${ }^{19}$ Confessions 1.16 .26 (et ob hoc bonae spei puer appellabar).

${ }^{20}$ Confessions III.4.1 (veni Carthaginem, et circumstrepebat me undique sartago flagitiosorum amorum).

${ }^{21}$ Confessions III.4.7 (ad acuendam linguam).

${ }^{22}$ Confessions IV.1.1 (hac popularis gloriae sectantes inanitatem, usque ad theatricos plausus et contentiosa carmina et agonem coronarum faenearum et spectaculorum nugas et intemperantiam libidinum).

${ }^{23}$ Murphy, "End of the Ancient World," 177.
} 
themes. ${ }^{24}$ The rhetorical environment of Augustine's boyhood was one "characterized by an exaggerated interest in oratorical declamation" and the "elaborate development of epideictic or demonstrative oratory." ${ }^{25}$ In retrospect, Augustine considered the environment of competitive rhetoric cultivated by his teachers to be "the threshold" on which he "stood in peril as a boy." ${ }^{\text {26 }}$ He viewed these declamations and contests as "all so much smoke without fire."27 They tempted young scholars with fleeting concerns, worldly rewards, and meaningless victories. The tournaments were a show for the student "who longs for fame as a fine speaker," ${ }^{28}$ and who will revel "in the applause they earned for the fine flow of well-ordered and nicely balanced phrases."29

This corrupt motivation for rhetorical success was compounded by what Augustine considered to be the immoral content of the material he was compelled to learn. The "whirlpool of debasement" ${ }^{130}$ was the pagan religious culture that grounded his studies. These "fruitless pastimes"31 that he pursued were the "hellish torrent" immorality into which he and his classmates were pitched. "The words are certainly not learnt any the more easily by reason of the filthy moral," he writes, "but filth is committed with greater confidence as a result of learning the words. ${ }^{33}$ He confesses that he took "sinful pleasure" ${ }^{\text {34 }}$ in this "wine of error," ${ }^{35}$ but, thinking back, he saw that his moral and

\footnotetext{
${ }^{24}$ Baldwin, 6, 10.

${ }^{25}$ Murphy, Rhetoric in the Middle Ages, 35-37. But, see also Conley (59) for a different view.

${ }^{26}$ Confessions 1.19 .30 (horum ego puer morum in limine iacebam miser).

${ }_{28}^{27}$ Confessions 1.17.27 (illa omnia fumus et ventus).

${ }^{28}$ Confessions 1.18 .29 (cum homo eloquentiae famam).

${ }^{29}$ Confessions I.18.28 (si autem libidines suas integris et rite consequentibus verbis copiose ornateque narrarent, laudati gloriabantur).

${ }^{30}$ Confessions 1.19 .30 (voraginem turpitudinis).

${ }^{31}$ Confessions 1.18 .28 (quid autem mirum, quod in vanitates ita ferebar).

${ }^{32}$ Confessions 1.16 .26 (flumen tartareum).

${ }^{33}$ Confessions 1.16 .26 (non omnino per hanc turpitudinem verba ista commodius discuntur, sed per haec verba turpitudo ista confidentius perpetratur)

${ }_{34}^{34}$ Confessions 1.16.26 (et eis delectabar miser).

${ }^{35}$ Confessions 1.16 .26 (vinum erroris).
} 
religious development would have been better served had he been put to the task of "studying something that matters." ${ }^{36}$

At the same time, Augustine does not condemn the discipline of rhetoric itself, but rather a corrupted and truncated residue of it. It is not classical rhetoric but this sophistic "cult of mere expression" and "absurd showmanship"37 that Augustine condemns, and which he mainly associates with infamy and with "man's insatiable desire" for wealth. ${ }^{38}$ And, implicitly at least, Augustine hints at the redemption of rhetoric. Through his rhetorical training he "was acquiring a command of words," although he admits he "did not care for lessons and disliked being forced to study," he acknowledges that "I was compelled to learn and good came to me as a result." 40 "These elementary lessons were more valuable than those which followed," he wrote, "because the subjects were practical." "I1 "I can speak and write," he tells God "and I want these things to be used to serve you. ${ }^{42}$

When he left school at age twenty-one he returned home to teach rhetoric in his native town of Thagaste. "I was a teacher of the art of public speaking," he explains, "I sold to others the means of coming off better in the debate. ${ }^{43}$ In the Confessions he condemns his own teaching of rhetoric in much the same language as that he used to censure the instruction he had received. Indeed, throughout the retrospective account

\footnotetext{
${ }^{36}$ Confessions 1.15 .24 (sed et in rebus non vanis disci possunt).

${ }^{37}$ W. H. Semple, "Augustinus Rhetor: A Study from the Confessions of St. Augustine's Secular Career in Education," Journal of Ecclesiastical History (1950), 137. See also Calvin L. Troup, Temporality, Eternity, and Wisdom: The Rhetoric of Augustine's Confessions (Columbia: University of South Carolina Press, 1999), 16.

${ }^{38}$ Confessions 1.12 .19 (praeterquam ad satiandas insatiabiles cupiditates copiosae inopiae).

${ }^{39}$ Confessions 1.20.31 (locutione instruebar)

${ }^{40}$ Confessions 1.12. (non amabam litteras et me in eas urgeri oderam, et urgebar tamen et bene mihi fiebat).

${ }^{41}$ Confessions 1.13 .20 (nam utique meliores, quia certiores, erant primae illae litterae).

${ }^{42}$ Confessions 1.15 .24 (tibi serviat quod loquor et scribo).

${ }^{43}$ Confessions IV.2.2 (docebam in illis annis artem rhetoricam, et victoriosam loquacitatem victus cupiditate vendebam).
} 
of his teaching career Augustine offers consistent evidence of what W. H. Semple called "the contempt of a great lover of truth for the unreality of the traditional rhetorical education."44 But, Augustine is never clear about which elements of the "traditional rhetorical education" he may have offered his own students. Although we know that Augustine was "imbued with the sophistic spirit of the age, ${ }^{45}$ he reveals nothing about the books on rhetoric he may have read as a student, or used in his teaching. So, what books of classical rhetoric did Augustine read? Or, what books did he assign his own students?

It is possible, of course, that Augustine had no theoretical training at all. As Michael Leff explains, during Augustine's era, "the end of rhetorical education was not theoretical knowledge but the acquisition of a personal power. Rhetoric was studied less for its own sake than as an instrument for developing a flexible verbal competence within the student." ${ }^{46}$ But, if Augustine did learn or teach more than the purely practical elements of rhetoric, we can be reasonably certain that his theoretical training was Ciceronian, for it is not only the case that Augustine was educated, and undertook his teaching duties against the background of a rhetorical culture that "was thoroughly Ciceronian, ${ }^{n 7}$ there is also significant scholarly consensus about the theoretical works that would have dominated the rhetorical curriculum of Augustine's time and the study of rhetoric throughout the Middle Ages. In addition to the many books "that

\footnotetext{
${ }_{45}^{44}$ Semple, 136. See also Outler, 214.

45 James J. Murphy, "St. Augustine and the Christianization of Rhetoric," Western Speech Communication Journal 22 (1958), 26.

${ }^{46}$ Michael Leff, "Acting and Understanding: A Note on the Relationship Between Classical and Contemporary Rhetoric," Federation Review: The Journal of the State Humanities Councils, 8 (1985), 7. ${ }^{47}$ Michael C. Leff, "St. Augustine and Martianus Capella: Continuity and Change in Fifth-Century Latin Rhetorical Theory," Communication Quarterly 24 (1976), 3. See also Peter Brown, Augustine of Hippo: A Biography (Berkeley: University of California Press, 1967), 36; Augustine Curley, "Cicero, Marcus Tullius," in Fitzgerald, ed., Augustine Through the Ages, 190-193. See also Pizzolato, 2-27.
} 
concentrated on school exercises, ${ }^{n 48}$ if Augustine read rhetorical theory as a student he almost certainly read either Cicero's De Inventione, or the pseudo-Ciceronian Rhetorica Ad Herennium, or both. De Inventione and Rhetorica ad Herennium were the "prevalent textbooks" throughout the Medieval period, ${ }^{49}$ and Augustine "probably knew the key school texts by memory." ${ }^{50}$ As James O'Donnell has concluded, "the central classical texts of Latin culture were ones he made his own in the schools of Madauros and Carthage, with rare facility." 51

At the same time, as Calvin Troup observes, although "Cicero's works were cherished as an important part of the Roman rhetorical curriculum" they "explicitly contradicted the institutional practice of the day. ${ }^{.52}$ Cicero's rhetorical theory assumed the unrestrained performance of deliberative and forensic oratory. The legal and political institutions of republican Rome "were necessary conditions for the kind of oratorical practice that stood at the center of the enterprise." Thus, although rhetoric students in Augustine's day may have learned theories of forensic rhetoric from the Ciceronian tradition, "as classical institutions decayed in later antiquity, the traditional rhetorical program gradually disintegrated. ${ }^{.53}$ In particular, as James Murphy explains, after the collapse of the Roman Republic, "freedom of speech was a major casualty."

\footnotetext{
${ }_{48}^{48}$ Murphy, "End of the Ancient World," 179.

${ }^{49}$ Baldwin, viii. See also Brian Vickers, In Defense of Rhetoric (Oxford: Clarendon, 1988), 216; Murphy, Rhetoric in the Middle Ages, 18; and Richard McKeon, "Rhetoric in the Middle Ages," in Rhetoric: Essays in Invention \& Discovery, ed. Mark Backman (Woodbridge, CT: Oxbow Press, 1987), 121. On these two Roman rhetoric texts see George A. Kennedy, The Art of Rhetoric in the Roman World, 300 B.C.-A.D. 300 (Princeton: University Press, 1972), 103-148.

${ }^{50}$ Troup, 19. See also Barbara Kursawe, docere delectare movere: Die official oratoris bei Augustinus in Rhetorik un Gnadenlehre (Paderborn: Ferdinand Schöningh, 2000). Kursawe argues that the essential features of Cicero's rhetorical doctrine influenced much of Augustine's thought and is in evidence in many of his works.

51 James J. O'Donnell, Augustine: A New Biography (New York: HarperCollins, 2005), 121. See also James J. Murphy, "The Metarhetorics of Plato, Augustine, and McLuhan: A Pointing Essay," Philosophy \& Rhetoric 4 (1971), 204.

${ }_{53}^{52}$ Troup, 17-18. See also Murphy, "St. Augustine and the Christianization of Rhetoric," 25.

${ }^{53}$ Leff, "Acting and Understanding," 8.
} 
Deliberative oratory was sacrificed to imperial will, and "Roman orators of the type represented by Cicero became less and less comfortable in the exercise of the second major type of speaking, the forensic oration. ${ }^{54}$

In Augustine's case, however, we can be reasonably certain that behind the contests of declamation, and the schoolroom emphasis on style, delivery, and performance, there remained a more substantial rhetoric rooted in the Ciceronian tradition. Indeed, it is this very tradition of Roman rhetorical theory that we find Augustine readily enlisting to compose one of the most compelling scenes in the Confessions. As Augustine investigates his own motives for stealing pears he turns to the method of classical forensic invention outlined by Cicero, and by the anonymous author of the Rhetorica Ad Herennium. As Augustine undertakes what he calls an "inquiry to discover why a crime has been committed"55 his text reveals the marks of this elementary rhetorical system. He wants to ask what his motive was, and wants to explore the "frame of mind"56 that led him to "do wrong for no purpose." As he conducts his investigation he employs the process of Roman forensic invention, and in particular seems to be drawing on the Rhetorica Ad Herennium. ${ }^{58}$

It is important to note that although Augustine investigates his former crime, he does not do so to defend his action, but to render that action understandable. In fact, while his forensic reflection is technically neither accusation nor defense, it is instructive

\footnotetext{
${ }_{55}^{54}$ Murphy, "End of the Ancient World," 177-78.

${ }^{55}$ Confessions 11.5 .11 (cum itaque de facinore quaeritur qua causa factum sit).

${ }^{56}$ Confessions II.9.17 (quid erat ille affectus animi? certe enim plane turpis erat nimis).

${ }^{57}$ Confessions 11.4 .9 (ut essem gratis malus et malitiae meae causa nulla esset nisi malitia).

${ }^{58}$ This work was commonly attributed to Cicero. The two Roman texts present a very similar system of invention, crafted in similar language, and either could serve to explain Augustine's inquiry. The parallels with the Rhetorica Ad Herennium are only slightly more illuminating. On Augustine's apparent use of these works at other places in the Confessions see: Marjorie O'Rourke Boyle, "A Likely Story: The Autobiographical as Epideictic," Journal of the American Academy of Religion 57 (1989), 27-28.
} 
to read the section on pear stealing as Augustine advancing an accusation against himself. In this sense, it is not surprising to find that he begins the matter with what the classical theorists called a "direct opening" designed to "enable us to have hearers who are attentive, receptive, and well-disposed."59 Such an introduction would be considered appropriate in cases where the cause is honorable. In an honorable cause "we either defend what seems to deserve defence by all men, or attack what all men seem in duty bound to attack." ${ }^{60}$ Certainly Augustine did not consider his theft to be honorable. Quite the opposite. He considers condemnation of that theft to be his duty. His actions, he writes, displayed a "lack of a sense of justice or a distaste for what was right and a greedy love of doing wrong. ${ }^{61}$ With a direct opening, writes the author of Rhetorica Ad Herennium, "we must begin our speech with a law, a written document, or some argument supporting our cause." ${ }^{.62}$ Augustine begins his account by reminding God that "theft is punished by your law, the law that is written in men's hearts and cannot be erased however sinful they are."63

We would expect a forensic accusation to follow with a narration or "statement of the facts" which should have "brevity, clarity, and plausibility." After his brief reflection on his sinfulness, Augustine tells his readers the story of the pear theft. The text at this point clearly shifts to a narrative style as he recalls that "Late one night a band ruffians,

${ }^{59}$ [Cicero] Ad C. Herennium De Ratione Dicendi (Rhetorica Ad Herennium), trans. Harry Caplan (Cambridge: Harvard University Press, 1981), I.iv.6 (id ita sumitur, ut attentos, ut dociles, ut benivolos auditores habere possimus).

${ }^{60}$ Rhetorica Ad Herennium I.iii.5 (honestum causae genus putatur, cum aut id defendimus, quod ab omnibus defendendum videtur, aut obpugnabimus, quod ab omnibus videtur obpugnari debere).

${ }_{62}^{61}$ Confessions II.4.9 (nulla compulsus egestate nisi penuria et fastidio iustitiae et sagina iniquitatis).

${ }^{62}$ Rhetorica Ad Herennium l.iv.6 (sin principio uti nolemus, ab lege, ab scriptura, aut ab aliquo nostrae causae adiumento principium capere oportebit).

${ }_{63}$ Confessions II.4.9 (furtum certe punit lex tua, domine, et lex scripta in cordibus hominum, quam ne ipsa quidem delet iniquitas).

${ }^{64}$ Rhetorica Ad Herennium I.viii.14 (tres res convenit habere narrationem, ut brevis, ut dilucida, ut veri similis sit). 
myself included, went off to shake down the fruit and carry it away." ${ }^{65}$ His narration lasts but a paragraph, and (following theoretical advice of Rhetorica ad Herennium) he neither tries "to recount from the remotest beginning, ${ }^{\text {"66 }}$ nor to "carry it forward," beyond "the point to which we need to go." ${ }^{67}$ Having conveyed the relevant facts of the case, Augustine focuses on the central issue, or what the rhetoricians called the "division of the cause," ${ }^{16}$ in which we clarify "what remains contested." ${ }^{19}$ The issue is discovered by "the joining of the primary plea of the defence with the charge of the plaintiff."

Of course, Augustine offers no defense. His point is to acknowledge the crime and to explain its genesis. Early in chapter IV, Augustine tells God that "I was willing to steal, and steal I did. ${ }^{171}$ Admitting the act and defining it as theft means that Augustine sees the matter as a juridical issue ${ }^{72}$ As the author of Rhetorica ad Herennium explains, "an issue is Juridical when there is agreement on the act, but the right or wrong of the act is in question." ${ }^{73}$ Of course, there is no controversy for Augustine about his stealing. Augustine freely acknowledges "the crime of theft, ${ }^{74}$ and moreover confesses that he "loved my own perdition and my own faults, not the things for which I

\footnotetext{
${ }^{65}$ Confessions II.4.9 (ad hanc excutiendam atque asportandam nequissimi adulescentuli perreximus nocte intempesta).

${ }^{66}$ Rhetorica Ad Herennium I.ix.14 (et si non ab ultimo initio repetere volemus).

${ }_{68}^{67}$ Rhetorica Ad Herennium l.ix.14 (et si non ad extremum, sed usque eo, quo opus erit, persequemur).

${ }^{68}$ Rhetorica Ad Herennium I.x.17 (causarum divisio).

${ }^{69}$ Rhetorica Ad Herennium I.X.17 (quid in controversiis relictum sit).

${ }^{70}$ Rhetorica Ad Herennium I.x.18 (constitutio est prima deprecatio defensoris cum accusatoris insimulatione coniuncta).

${ }_{71}^{71}$ Confessions II.4.9 (et ego furtum facere volui et feci).

72 The third type of issue is elsewhere commonly called "qualitative" - that is, it inquires into the quality or nature of the act to see whether it can in some fashion be justified or excused. Here, I follow the vocabulary used by the author of Rhetorica ad Herennium. But, see also Cicero, De Inventione I.xi.1214.

${ }^{73}$ Rhetorica Ad Herennium I.xiv.24 (/uridicialis constitutio est, cum factum convenit, sed iure an iniuria factum sit, quaeritur).

${ }^{74}$ Confessions II.4.9 (quid ego miser in te amavi, o furtum meum, o facinus illud meum nocturnum).
} 
committed wrong, but the wrong itself. ${ }^{175}$ However, only by identifying the issue as a juridical one, and in particular a juridical issue of the assumptive variety, can he move into the territory of surveying the motives for doing wrong.

The author of Rhetorica ad Herennium tells us that "the issue is Assumptive when the defence, in itself insufficient, is established by drawing on extraneous matter. ${ }^{.76}$ In other words, in this act of self-accusation Augustine seeks to know whether there was any excuse at all for his conduct, or whether it was merely that his "soul was vicious," assumptive issue allows for an "acknowledgment of the charge," (concessio) in which the defendant can "plea for mercy" (deprecatio). In such a case, "the defendant confesses the crime and premeditation, yet begs for compassion." ${ }^{79}$ In the Roman republic such a strategy was "rarely practicable," but for Augustine as a repentant sinner it is the only available course of action.

But the questions remain. "Immediately upon finding the Type of Issue, then, we must seek the Justifying Motive," writes the author of Rhetorica Ad Herennium. ${ }^{80}$ So, Augustine asks, "What conclusions am I trying to reach from these questions and this

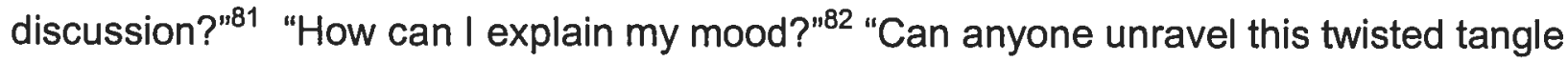

\footnotetext{
${ }^{75}$ Confessions II.4.9 (foeda erat, et amavi eam. amavi perire, amavi defectum meum, non illud ad quod deficiebam, sed defectum meum ipsum amavi).

${ }^{76}$ Rhetorica Ad Herennium I.xiv.24 (adsumptiva pars est, cum per se defensio infirma est, adsumpta extraria re conprobatur)

${ }_{78}$ Confessions 11.4 .9 (turpis anima).

${ }_{78}^{78}$ Confessions 11.6 .14 (o putredo).

${ }^{79}$ Rhetorica Ad Herennium I.xiv.24 (deprecatio est, cum et peccasse se et consulto fecisse confitetur, et tamen postulat, ut sui misereantur).

${ }_{81}^{80}$ Rhetorica Ad Herennium I.xvi.26 (constitutione igitur reperta statim quaerenda ratio est).

${ }^{81}$ Confessions 11.8 .16 (quid est? quod mihi venit in mentem quaerere et discutere et considerare).

${ }^{82}$ Confessions II.9.17 (quid erat ille affectus animi).
} 
of knots? ${ }^{83}$ Augustine proceeds with a forensic analysis of the crime, probing the possible motives, justifications, or excuses that could be offered to explain or defend his action. In seeking a motive the classical rhetorician would ask: "Did he seek some benefit from the crime - honour, money, or power? Did he wish to satisfy some passion - love or a like overpowering desire? Or did he seek to avoid some disadvantage enmities, ill repute, pain, or punishment?"84

Augustine notes that "normally no one is satisfied until it has been shown that the motive might have been either the desire of gaining, or the fear of losing one of those good things which I said were of the lowest order. ${ }^{\text {"85 }}$ But, he is left to ask "what pleasure I had in that theft?" "honour, power, and wealth" as Catiline had done? Did he do the crime out of "fear" or "anger," or "ignorance"? Did it result from "pernicious habit?" "What was it," he asks, "that pleased me in that act of theft?" ${ }^{87}$ The best he can do in considering his "feelings at the time" is to attribute the crime to peer pressure. "I would not have done it on my own," he confesses. ${ }^{88}$ "For the sake of a laugh, a little sport," he concludes, "I was glad to do harm and anxious to damage another; and that without thought of profit for myself or retaliation for injuries received." ${ }^{89}$

\footnotetext{
${ }^{83}$ Confessions II.10.18 (quis exaperit istam tortuosissimam et implicatissimam nodositatem).

${ }^{84}$ Rhetorica Ad Herennium II.ii.3 (cum quaeritur, num quod commodum maleficio appetierit, num honorem, num pecuniam, num dominationem; num aliquam cupiditatem aut amoris aut eiusmodi libidinis voluerit explere, aut num quod incommodum vitarit: inimicitias, infamiam, dolorem, supplicium).

${ }^{85}$ Confessions 11.5 .11 (credi non solet, nisi cum appetitus adipiscendi alicuius illorum bonorum quae infima diximus esse potuisse apparuerit aut metus amittendi).

${ }^{86}$ Confessions II.6.12 (quaero quid me in furto delectaverit).

${ }^{87}$ Confessions II.6.14 (quid ergo in illo furto ego dilexi).See also Confessions III.8.16.

${ }^{88}$ Confessions II.8.16 (et tamen solus id non fecissem [sic recordor animum tunc meum] solus omnino id non fecissem).

${ }^{89}$ Confessions II.9.17 (ex ludo et ioco nocendi aviditas et alieni damni appetitus nulla lucri mei, nulla ulciscendi libidine).
} 
Still, the main forensic response for Augustine is confession. "We shall use the Plea for Mercy when we confess the crime without attributing it to ignorance, chance, or necessity, and yet beg for pardon. ${ }^{.90}$ By his forensic analysis of the case, Augustine has effectively eliminated any of the available justifications or excuses. It is true that he here departs from the recommended strategy of the rhetoricians. He does not expound on his good deeds, or reflect on his own virtue. In the end, as a Christian, Augustine cannot rely on his own merits, but must appeal to God, and to "the mercy by which you forgive the sins of the penitent." and mercy that you melted away my sins like ice." 92

This analysis of the pear-stealing episode suggests that Augustine had come to know the system of Roman forensic invention instinctively, and so may have relied upon De Inventione or Rhetorica ad Herennium in teaching rhetoric to his students. Yet is seems to have been his teaching of Ciceronian rhetoric that led him to recognize (at least in retrospect) the moral dilemma associated with classical forensic discourse. He taught his students the "tricks of pleading," but he "had no evil intent"93 and "never meant them to be used to get the innocent condemned but, if the occasion arose, to save the lives of the guilty." ${ }^{14}$ To save a life is certainly a good, but to do so by means of what Augustine called "schemes of duplicity" could not be approved. He could only reassure himself with the reminder that "I did my best to teach them honestly."

\footnotetext{
${ }^{90}$ Rhetorica Ad Herennium II.xvii.25 (Deprecatione utemur, cum fatebimur nos peccasse neque id inprudentes, aut fortuito aut necessario fecisse dicemus: et tamen ignosci nobis postulabimus).

${ }^{91}$ Confessions 11.7 .15 (misericordia tua, qua donas peccata conversis ad te).

${ }^{92}$ Confessions II.7.15 (gratiae tuae deputo et misericordiae tuae quod peccata mea tanquam glaciem solvisti).

${ }^{93}$ Confessions IV.2.2 (et eos sine dolo docebam).

${ }_{94}^{94}$ Confessions IV.2.2 (non quibus contra caput innocentis agerent sed aliquando pro capite nocentis).

${ }^{95}$ Confessions IV.2.2 (quam exhibebam in illo magisterio diligentibus vanitatem et quaerentibus mendacium, socius eorum.).
} 
The rather severe censure of his own teaching leads us to conclude that it, too, was largely sophistic in orientation, even if he did use some of the theoretical material from the Roman rhetoricians. "I sold the services of my tongue," he confesses, and he led his students to learn "lies and the insane warfare of the courts." ${ }^{96}$ He always wanted "to have honest students, insofar as honesty has any meaning nowadays," ${ }^{97}$ but there is little doubt that, in retrospect, he considered such rhetoric lessons as contributing to the corruption of his students and himself. It is with a palpable sense of regret, for example, that he recalls the occasion when he was "preparing a speech in praise of the emperor," and shamelessly composed "a great many lies which would certainly be applauded by an audience who knew well enough how far from the truth they were." ${ }^{\prime 98}$

Augustine invokes the same criterion in assessing the public speaking of two prominent citizens he discusses in the Confessions. We see this sharper ethical criticism in his retrospective judgment of Faustus and Ambrose. Hearing the Manichean bishop Faustus, Augustine recalled that "many people were trapped by his charming manner of speech," but that Augustine "was beginning to distinguish between mere eloquence and the real truth, which I was so eager to learn." ${ }^{.99}$ As he considers the matter further, Augustine offers us an extended reflection on his critical principles. Some people had thought Faustus wise "simply because they were charmed by his manner of speech." ${ }^{100}$ But he concludes that style and eloquence alone are no

\footnotetext{
${ }^{96}$ Confessions IX.2.2 (sed leniter subtrahere ministerium linguae meae nundinis loquacitatis . . . sed insanias mendaces et bella forensia).

${ }_{97}$ Confessions IV.2.2 (malebam tamen, domine, tu scis, bonos habere discipulos, sicut appellantur boni).

${ }^{98}$ Confessions VI.6.9 (cum pararem recitare imperatori laudes, quibus plura mentirer et mentienti faveretur ab scientibus).

${ }^{99}$ Confessions V.3.3 (et multi implicabantur in eo per inlecebram suaviloquentiae. quam ego iam tametsi laudabam, discernebam tamen a veritate rerum quarum discendarum avidus eram).

${ }^{100}$ Confessions V.6.10 (et ideo illis videbatur prudens et sapiens, quia delectabat eos loquens).
} 
guarantee of wisdom. "Wisdom and folly can be clothed alike in plain words or the finest flowers of speech." 101

In contrast, Augustine proposes the figure of Ambrose as the model pastor and eloquent Christian. At first, Augustine sets out to "judge for myself whether the reports of his powers as a speaker were accurate, or whether eloquence flowed from him more, or less, readily than I had been told. ${ }^{102}$ Ambrose had a "charming delivery" but in Augustine's opinion "had not the same soothing and gratifying manner" as Faustus. ${ }^{103}$ As Augustine recalls his experience, he tried to ignore the substance of Ambrose's message, and aimed to focus merely on "the manner in which he said it." But, the truth was irresistible. "I could not keep the two apart," Augustine writes, "and while I was all ears to seize upon his eloquence, I also began to sense the truth of what he said.."104 Thus, although at the time Augustine had "not yet discovered that what the Church taught was the truth," ${ }^{105}$ in retrospect he recognized that what gave Ambrose the advantage as a preacher was the substance of his message, "Ambrose taught the doctrine of salvation. ${ }^{106}$

As both his censure of his own teaching, and the application of his critical faculties to the discourse of Faustus and Ambrose make clear, by the time he composed the Confessions Augustine had developed a new Christian ethics of rhetoric. Writing a decade after he resigned as professor of rhetoric, Augustine had time to work

\footnotetext{
${ }^{101}$ Confessions V.6.10 (sed perinde esse sapientiam et stultitiam sicut sunt cibi utiles et inutiles, verbis autem ornatis et inornatis sicut vasis urbanis et rusticanis utrosque cibos posse ministrari).

${ }^{102}$ Confessions V.13.23 (quasi explorans eius facundiam, utrum conveniret famae suae an maior minorve proflueret quam praedicabatur).

${ }^{103}$ Confessions V.13.23 (delectabar suavitate sermonis, quamquam eruditioris, minus tamen hilarescentis atque mulcentis quam Fausti erat).

${ }_{104}$ Confessions V.14.24 (neque enim ea dirimere poteram. et dum cor aperirem ad excipiendum quam diserte diceret, pariter intrabat et quam vere diceret, gradatim quidem).

${ }^{105}$ Confessions VI.4.5 (etsi nondum compertam vera docentem).

${ }^{106}$ Confessions V.13.23 (ille autem saluberrime docebat salutem).
} 
out some of the conflicts between his former profession and his present commitments as a Christian and a bishop. The Confessions had given him some historical distance and a critical space with which to assess his rhetorical studies and teaching career. While we see one facet of that critique in the narrative of the Confessions, the more productive dimensions of his critical and theoretical review of rhetoric are worked out in the De Doctrina Christiana. For a student of rhetoric, then, these two works have to be read together.

\section{The Confessions and De Doctrina Christiana.}

W. R. Johnson has called Augustine "the last of the great ancient rhetoricians,"107 an assessment widely shared, and justified by the influence of Augustine's De Doctrina Christiana. The work occupies a central position in the scholarship on medieval rhetoric, and, in rhetorical terms, is considered "the clearest bridge to the Middle Ages." ${ }^{108}$ The De Doctrina Christiana was "the first manual of Christian rhetoric," ${ }^{109}$ and "the first homiletic."110 With it, according to Charles Sears Baldwin, Augustine "begins rhetoric anew." ${ }^{111}$

This "authoritative statement of Christian rhetoric" was addressed by the Bishop of Hippo to his Christian clergy and served to explain Augustine's views on "how to discover (the modus inveniendi) what is to be understood in scripture," and "how to teach (the modus proferendi) what has been understood."112 Augustine wrote the first three books in 396, the year before he began work on the Confessions, then put the

\footnotetext{
${ }^{107}$ W.R. Johnson, "Isocrates Flowering: The Rhetoric of Augustine," Philosophy \& Rhetoric 9 (1976), 217.

${ }^{108}$ Murphy, "End of the Ancient World," 183.

${ }^{109}$ Murphy, Rhetoric in the Middle Ages, 58. See also Marrou, esp. 505-540.

${ }_{110}^{110}$ Baldwin, 72.

${ }^{111}$ Baldwin, 51.

${ }^{112}$ Conley, 76 . Kennedy calls the work a combination of "hermeneutics and homiletics" and also a presentation on "the arts of exegesis and of preaching," (Classical Rhetoric, 158.)
} 
manuscript aside for nearly thirty years, composing the fourth and final book in 427 , only three years before he died. It is the fourth book, dedicated to preaching, that is widely understood as "St. Augustine's formal presentation of his rhetorical doctrine."113 And, as might be expected, most of the scholarship on Augustine's rhetoric is devoted to analysis and discussion of this portion of the De Doctrina Christiana.

Broadly speaking, that scholarship aims at investigating three major issues. First, rhetorical theorists and historians have been interested in exploring how Augustine framed "a theoretical warrant for the transformation of pagan literacy to Christian literacy." ${ }^{114}$ In this sense, rhetoricians read the De Doctrina Christiana as "a plea for the use of eloquentia in Christian oratory," ${ }^{115}$ and these scholars aim to assess Augustine's role in the "Christianization" of rhetoric. Contrary to the impression given in the Confessions, the De Doctrina Christiana reveals clearly that Augustine thought "the art of eloquence should be put into active service, and not rejected out of hand because it is tainted with paganism." ${ }^{116}$ As George Kennedy has pointed out, Augustine's position is that "neither eloquence nor skill at disputation is unchristian." In fact, "not only may a Christian use dialectic and rhetoric, but a Christian bishop must do so."117

The second concern of rhetoric scholars has to do with tracing Augustine's influence on the rhetoric of the Middle Ages. According to those scholars who have studied the matter, the De Doctrina Christiana "had significant influence on Carolingian

\footnotetext{
113 Riley, 374

114 Johnson, 222.

115 Murphy, Rhetoric of the Middle Ages, 58.

${ }^{116}$ Murphy, "Christianization of Rhetoric," 408. See also Cipriani.

117 Kennedy, Classical Rhetoric, 152; see also Murphy, "Saint Augustine and the Christianization of Rhetoric," and "Saint Augustine and the Debate About a Christian Rhetoric," Quarterly Journal of Speech 46 (1960), 400-410.
} 
and later medieval times."118 That influence is "clearly visible," by the fact that Augustine's work was "copied or quoted by such writers as Rabanus Maurus in the ninth century, Alain de Lille in the twelfth, Humbert of Romans in the thirteenth, and Robert of Basevorn in the fourteenth."119

Finally, rhetoricians are interested in understanding the extent to which Augustine appropriates the theoretical doctrine of Roman rhetoric for his own directives on preaching. These studies have tended to focus on the origins or sources of Augustine's ideas, and are directed in particular to documenting the extent and dimensions of Cicero's influence on Augustine's rhetorical program. As various scholars have observed, Augustine's work is "studded with references to Cicero"120 who is the "unquestioned source of Augustine's rhetorical precepts." 121 Indeed, wrote Troup, the Ciceronian influence is now taken for granted, and is "so well documented and widely accepted" that it can be considered a closed question. ${ }^{122}$ According to Ernest $\mathrm{L}$. Fortin, "scholars are virtually unanimous in asserting that Augustine remains by and large faithful to the Ciceronian tradition." ${ }^{123}$

But while many rhetoricians follow James Murphy in reading De Doctrina Christiana as a "strong argument that the Church should use the rhetoric of Cicero to

\footnotetext{
${ }^{118}$ Kennedy, Classical Rhetoric, 159. See also James J. Murphy, "Saint Augustine and Rabanus Maurus: The Genesis of Medieval Rhetoric," Western Speech Communication Journal 31 (1967); and Leff, "Saint Augustine and Martianus Capella."

${ }_{119}$ Murphy, Rhetoric of the Middle Ages, 47.

${ }_{120}^{120}$ Leff, "St. Augustine and Martianus Capella," 4.

121 John H. Patton, "Wisdom and Eloquence: The Alliance of Exegesis and Rhetoric in Augustine," Central States Speech Journal 28 (1977) 120.

${ }^{122}$ Troup, 25. See also Peter Prestel, Die Rezeption der ciceronischen Rhetorik durch Augustinus in "de doctrina Christiana" (Frankfurt am Main: Peter Lang, 1992).

${ }^{123}$ Ernest L. Fortin, "Augustine and the Problem of Christian Rhetoric," Augustinian Studies 5 (1974), 86. See also James J. Murphy, "Cicero's Rhetoric in the Middle Ages," Quarterly Journal of Speech, 52 (1967), 334.
} 
convey its message through preaching and education," ${ }^{124}$ others have not let the close affinity with Cicero obscure the significant innovations in rhetorical theory advanced by Augustine. Fortin maintains that "Augustine has in fact profoundly modified the Ciceronian doctrine, ${ }^{125}$ and Leff has argued that the key difference can be seen in Augustine's concern for his audience. In contrast to Cicero, "to Augustine, the orator's purpose had to be referred 'not to the temporal welfare of man, but to his eternal welfare'."126 In a similar fashion, Murphy remarks that Augustine's rhetoric "posits the innate humanity of both speaker and audience member," and Christian love obligates the orator "to assist his neighbor in learning about the universe and God." ${ }^{127}$ Thus, "the major discovery shaping Augustine's thought," according to Scanlon, "is caritas."128 Understanding the explicit ethics of rhetoric articulated in De Doctrina Christiana permits us to reassess Augustine's comments about rhetoric in the Confessions. The De Doctrina Christiana is the major premise in Augustine's argument against sophistic rhetoric, with the minor premise presented in the particulars of his experience as narrated in the Confessions. Having crafted the main part of De Doctrina Christiana only the year before composing the Confessions Augustine could rely on his mature Christian ethical perspective to assess his own experience as a student and as a professor of rhetoric. It is useful for us, then, to read the critique of rhetoric in the Confessions through the ethical lens provided by De Doctrina Christiana.

\footnotetext{
${ }_{124}^{124}$ Murphy, "End of the Ancient World," 183.

${ }^{125}$ Fortin, 87. See also Anthony Mazzeo, "St. Augustine's Rhetoric of Silence," Journal of the History of ldeas 23 (1962), 175-76, and Pizzolato, esp. 47-73. .

${ }^{126}$ Leff, "'st. Augustine and Martianus Capella," 6. Leff is quoting De Doctrina Christiana, IV.xviii.35.

${ }^{127}$ Murphy, "Metarhetorics," 208.

${ }^{128}$ Michael J. Scanlon, O.S.A., "Augustine and Theology as Rhetoric," Augustinian Studies 25 (1994), 43.
} 
While most rhetoric scholars have focused their historical interest and analytical skills on the fourth book of De Doctrina Christiana, it is in fact the first book of that work in which Augustine spells out his new ethics of rhetoric. In the opening paragraph, Augustine explains his twofold purpose for writing. He wants to offer guidance to those who will be "treating the Scriptures," and who must offer "explanations of the sacred writings to others." 129 He looks to advise his clergy on "a way of discovering those things which are to be understood, and a way of teaching what we have learned." ${ }^{130}$ To properly understand Augustine's treatment of hermeneutics and homiletics we need to take seriously his advice to his clergy that "all your thoughts and all your life and all your understanding should be turned toward Him from whom you receive these powers." ${ }^{131}$ He tells us that the task of communicating our understanding of sacred Scripture should always be undertaken "without pride or envy," ${ }^{132}$ and always with charity, "which holds men together in a knot of unity." ${ }^{133}$ Our exegetical work, as well as our preaching, should always be "useful for the building of charity." ${ }^{134}$ In addition, all our rhetoric should be grounded on "the rule of truth." ${ }^{\text {"135 }}$ Each Christian is called to "conform himself to truth"136 and "those who seek the truth," ${ }^{137}$ in fact seek "Him who is the truth." ${ }^{138}$ The De Doctrina Christiana proposes a sacramental rhetoric, the key to which

\footnotetext{
${ }^{129}$ Saint Augustine, On Christian Doctrine (De Doctrina Christiana), trans. D. W. Robertson, Jr. (Indianapolis: Bobbs-Merrill, 1979), prologue.1 (quaedam tractandarum Scripturarum ... ipsi aperiendo proficiant).

${ }^{130}$ De Doctrina Christiana I.1.1 (modus inveniendi quae intellegenda sunt et modus proferendi quae intellecta sunt).

${ }^{131}$ De Doctrina Christiana 1.22.21 (ut omnes cogitationes tuas et omnem vitam et omnem intellectum in illum conferas, a quo habes ea ipsa quae confers).

${ }_{132}$ De Doctrina Christiana prologue.5 (sine superbia et sine invidia).

${ }^{133}$ De Doctrina Christiana, prologue.6 (quae sibi homines invicem nodo unitatis astringit).

${ }^{134}$ De Doctrina Christiana I.36.40 (ut huic aedificandae caritati sit utilis).

${ }^{135}$ De Doctrina Christiana 1.8 .8 (regulam veritatis).

${ }^{136}$ De Doctrina Christiana I.20.19 (configurari veritati).

${ }^{137}$ De Doctrina Christiana 1.24 .25 (qui sine pertinacia verum requirunt).

${ }^{138}$ De Doctrina Christiana prologue.7 (illi qui est veritas).
} 
the relationship of discourse, speaker, and audience to God. The ideal audience for Augustine's Christian rhetoric, then, are "all those who wish to arrive at truth and rest in eternal life."139

Moreover, Augustine writes, the purpose or end of preaching should be the salvation of those to whom we speak. "Every man," he writes, "should be loved for the sake of God." 140 And so, when we teach, "we should desire that all enjoy God with us and that all the assistance we give them or get from them should be directed toward that end." ${ }^{141}$ When Christian orators direct their rhetoric charitably toward the salvation of others their discursive efforts must always be given freely. Augustine sees rhetoric as a gift, a talent received from God which is used in his service to bring others to the truth. God has "given to each gifts proper to the building of His Church," ${ }^{142}$ and such gifts do "not decrease on being given away." 143 Those "benevolently using that which they have received"144 will receive from God "a wonderful abundance"145 of ideas.

In short, that rhetoric is worthy of a Christian which is founded on truth, which builds up charity, and which moves us toward eternal life. As Scanlon explains, "The old ideal of rhetoric — verbal mastery of the audience by the orator-is radically changed. The Christian orator is an orans, one who prays with others in a community of equals." ${ }^{146}$ Understanding this new ethics of sacramental rhetoric, we can begin to

\footnotetext{
${ }^{139}$ De Doctrina Christiana I.34.38 (omnibus qui ad veritatem pervenire et in vita aeterna permanere desiderant).

${ }^{140}$ De Doctrina Christiana 1.27.28 (et omnis homo in quantum homo est, diligendus est propter Deum); see also Murphy, "Metarhetorics," 208.

${ }^{141}$ De Doctrina Christiana 1.29 .30 (Velle tamen debemus ut omnes nobiscum diligant Deum, et totum quod eos vel adiuvamus vel adiuvamur ab eis ad unum illum finem referendum est).

${ }_{143}^{142}$ De Doctrina Christiana I.15.14 (et dona unicuique propria ad instructionem Ecclesiae suae).

${ }_{143}^{143}$ De Doctrina Christiana I.1.1 (Omnis enim res quae dando non deficit).

${ }_{145}^{144}$ De Doctrina Christiana I.1.1 (cum benignitate utentibus eo quod acceperunt).

${ }^{145}$ De Doctrina Christiana I.1.1(mirabili abundantia).

${ }^{146}$ Scanlon, 45.
} 
illuminate Augustine's censure of the sophistic rhetoric that saturated the schools and public culture of the late Roman Empire. As the critical remarks on rhetoric in the narrative make clear, the Confessions signals something more than the account of a religious conversion. Reflecting on his rhetorical past from the Christian perspective of the Confessions Augustine is invoking the new ethics of his sacramental rhetoric. As Floyd K. Riley writes, "St. Augustine's professional point of view underwent revolution." ${ }^{147}$

Augustine's critique of his rhetorical education, his own teaching, and his practice of rhetoric, is all directed to the question of whether his action and his discourse served truth and charity. The rhetoric of the second sophistic, the rhetorical culture in which he was educated, and in which he educated others, left truth as a secondary concern. The Confessions therefore challenges the overt instrumental pragmatism of the sophistic program. The rhetoric Augustine learned and taught sought to address, indeed to charm, an audience for the purpose of gaining victory, power, fame, or wealth. The rhetoric, then, is mainly selfish; the members of the audience are offered the pleasures of the text as they are made mere means to some end pursued by the orator. Augustine recognized that such a rhetoric is uncharitable. It fails to recognize the inherent dignity of other human beings as it turns them into mere instruments in the accomplishment of the speaker's purpose. In the end, sophistic rhetoric does nothing to bring about the Kingdom of God. ${ }^{148}$

\footnotetext{
${ }^{147}$ Floyd K. Riley, "St. Augustine, Public Speaker and Rhetorician," Quarterly Journal of Speech 22 (1936), 572. See also Troup, 28-32.

${ }_{48}$ On this point see Joseph Cardinal Ratzinger (Pope Benedict XVI), Introduction to Christianity (San Francisco: Ignatius Press, 1990), 74-79.
} 
This, then, is one of the startling differences between classical rhetoric and Augustine's sacramental Christian rhetoric. In the classical attitude, the end of discourse is always victory for the speaker. The purpose is persuasion of an audience to accomplish what the speaker defines as good or just. With Augustine, the good and the just are presupposed, and the purpose of discourse is to utter that truth for the good of the audience. How much of this new ethics of rhetoric was actually part of Augustine's migration from the classroom to the baptismal is hard to know. Yet once he begins to focus intently on the question of truth in the Confessions he vows to no more be a "vendor of words," 149 in such a culture. His students would no longer buy from his lips "any weapon to arm their madness." ${ }^{\text {150 }} \mathrm{He}$ rejects the sophistic rhetoric of the Roman schools and quits his "chair of lies."151 Since there was "no salvation in the rhetoric,"152 and "we are too weak to discover the truth by reason alone," ${ }^{153}$ Augustine takes his own advice, to "entrust to the Truth all that the Truth has given to you, and nothing will be lost." ${ }^{154} \mathrm{He}$ "began at last to serve [God] with [his] pen."155 Part of that service was the Confessions.

\section{Confessions as Rhetoric}

In reflecting on the sixteenth centenary of the conversion of Saint Augustine, Pope John Paul II wrote that the Confessions was "a work that is simultaneously autobiography, philosophy, theology, mysticism and poetry." 156 What His Holiness did

\footnotetext{
${ }^{149}$ Confessions IX.5.13 (venditorem verborum).

${ }^{150}$ Confessions IX.2.2 (arma furori suo).

${ }^{151}$ Confessions IX.2.4 (cathedra mendacii).

${ }^{152}$ Confessions VIII.2.5 (non enim erat salus quam docebat in rhetorica).

${ }_{154}$ Confessions VI.5.8 (ideoque cum essemus infirmi ad inveniendam liquida ratione veritatem).

${ }_{154}$ Confessions IV.11.16 (veritati commenda quidquid tibi est a veritate, et non perdes aliquid).

${ }_{156}$ Confessions IX.4.7 (ibi quid egerim in litteris iam quidem servientibus tibi).

156 John Paul II, "Augustinum Hipponensem" August 28, 1986, I.

[http://www.cin.org/jp2ency/augustin.html]
} 
not mention is that the Confessions is also rhetoric. When we say that this work, which is viewed as the archetypal spiritual autobiography, is rhetoric, we mean no more than that the author intended the work to address an audience and to function instrumentally in the world. The Confessions, in other words, was meant by Augustine to influence his readers, and by means of language and form to direct their attitudes and conduct, to teach them, to delight them, to move them.

Several scholars have proposed that the Confessions be understood from a rhetorical perspective. Marjorie O'Rourke Boyle argued that "the Confessions is epideictic rhetoric," a text which is more than "a sack of ideas," but rather one in which Augustine "praises himself as good in God's works and blames himself as evil in his own works." ${ }^{n 157}$ Jamie Scott sees the work as a "publicly instructive" effort to offer "a written self to his fellow Christians as exhortation, ${ }^{158}$ while Brian Stock has explored the dimensions of Augustine's writing as ethical literature, noting that "all ethical statements contain an element of rhetoric. They are all performances directed toward audiences. ${ }^{159}$ Calvin Troup also bases his treatment of the work on the assumption that "the performative dimension inherent in Augustine's Confessions is consciously rhetorical." In Troup's understanding, the Confessions is a "public discourse directed toward an audience with the intention of influencing their social behavior." ${ }^{160}$

What does it mean, however, to explore the Confessions as rhetoric? What critical questions does the rhetorician bring to the work that may yield a fuller

${ }_{158}^{157}$ Boyle, 24-25. See also Finaert, Saint Augustin Rhéteur, 74-78.

158 Jamie Scott, "From Literal Self-Sacrifice to Literary Self-Sacrifice: Augustine's Confessions and the Rhetoric of Testimony," in Augustine: From Rhetor to Theologian. Edited by Joanne McWilliam (Waterloo, Ontario: Wilfrid Laurier University Press, 1992), 39.

159 Brian Stock, "Ethical Values and the Literary Imagination in the Later Ancient World," New Literary History 29 (1998), 4 .

${ }^{160}$ Troup, $5,54$. 
understanding of its rhetorical dimensions? Before we undertake that inquiry I want suggest that we begin by extending the connections between the De Doctrina Christiana, and the Confessions, reading the latter work in the context of the explicit statement of rhetorical ethics extracted from the former. In other words, we should begin our examination of the rhetoric of the Confessions by taking for granted that Augustine would not have composed a rhetorical work that obviously violated the ethics of rhetoric he had only very recently crafted himself. Let us begin our inquiry, then, keeping in mind that to Augustine all rhetoric "must be referred, not to the temporal welfare of man, but to his eternal welfare and to the avoidance of eternal punishment. ${ }^{161}$ For Augustine, after his conversion, rhetoric is fundamentally and essentially pastoral. In his view the value of the ancient discipline is discovered in its contribution to the spiritual health of Christians. The purpose of rhetoric is the care of souls. The end of the eloquence is eternal salvation.

\section{A. To whom was this work addressed?}

Did Augustine have a particular audience in mind? To whom were his words addressed, when he wrote of "the many who will read" his Confessions? ${ }^{162}$ James Seibach suggests that Augustine's audiences "are quite varied," and include, among others, "Manichees, skeptics and also Christians," as well as "God Himself,"163 while Calvin Troup argues that the Confessions was intended for a "loosely affiliated network of highly educated laymen, nuns, monks, priests, and bishops spread throughout the

\footnotetext{
${ }^{161}$ De Doctrina Christiana IV.18.35 (ad hominum salutem nec temporariam sed aeternam referre debemus, ubi etiam cavendus est aeternus interitus).

${ }^{162}$ Confessions X.1.1 (in stilo autem meo coram multis testibus).

163 James Siebach, "Rhetorical Strategies in Book One of St. Augustine's Confessions," Augustinian Studies 26 (1995), 93-108.
} 
Roman Empire." ${ }^{164}$ There is certainly textual evidence to remind us of those among Augustine's contemporaries who were to be the likely readers of his work. And yet, more than sixteen centuries later, we are still reading Augustine's text with questions of our own, in universities and communities that did not exist, in languages that were not yet formed, when he first set out to address his readers. Are we not also Augustine's audience? ${ }^{165}$

When we consider the Confessions as pastoral rhetoric, we are encouraged to look beyond the immediate historical context of the late fourth century to discover Augustine's audience. Indeed, we should take Augustine at his word when he leads us in this direction. Early in the work, he expressly excludes from his audience those who would reject the sacramental premise of his pastoral rhetoric. "Let the proud deride me, O God, and all whom you have not yet laid low and humiliated for the salvation of their souls." ${ }^{166}$ In Book X, he imagines his audience to be his "true brothers," that is, "those who rejoice for me in their hearts when they find good in me, and grieve for me when they find $\sin ^{\prime 167}$ and those also who share God's kingdom and "accompany me on this pilgrimage, whether they have gone before or are still to come or are with me as I make my way through life. ${ }^{168}$ Augustine's audience, then, consists of Christians of all ages. He writes for the Communion of Saints. He imagines the readers of his Confessions to be any of the "believers among men, all who share my joy and all who, like me, are

\footnotetext{
164 Troup, 44.

${ }^{165}$ In my analytical approach to the question of audience and influence I draw on the work of Edwin Black. See Rhetorical Criticism: A Study in Method (1965; Madison, University of Wisconsin Press, 1978).

${ }^{166}$ Confessions IV.1.1 (inrideant me arrogantes et nondum salubriter prostrati et elisi a te, deus meus).

${ }^{167}$ Confessions X.4.5 (sed fraternus ille, qui cum approbat me, gaudet de me, cum autem improbat me, contristatur pro me, quia sive approbet sive improbet me, diligit me. indicabo me talibus).

${ }^{168}$ Confessions X.4.6 (et mecum peregrinorum, praecedentium et consequentium et comitum vitae meae).
} 
doomed to die." ${ }^{\prime 169}$ We are encouraged then to think that for all these readers, and for us, Augustine has the same pastoral concern he directed to the Christians of his diocese during his lifetime.

In considering this expanded scope of Augustine's audience, we see not only the extended reach of Augustine's charity, but also better understand our own relationship to the text. If we view the Confessions as addressed to the ages, and not strictly limited by the historical confines of Augustine's age, we begin to understand the enduring influence of the work. Augustine deals in abiding truths and universals; even his particulars function as parables, disclosing what is common to the human condition, and directing all readers toward the understanding of their dependence on God. As Frances Young observed, Augustine "makes himself an instance of the universal human story." ${ }^{170}$ As readers of Augustine's work, even those who approach his Confessions so many centuries later, we are meant to see the meaning of his text for our own lives. As Pope John Paul believed, Augustine, "has much to teach the men and women of today." 171

In its own time, Augustine's Confessions represented a cultural shift, from pagan sensibilities to a Christian commitment. It is a challenge that is both narrated in the text, and embodied in the theology and rhetoric of Augustine's writing. One could not be among Augustine's "true brothers" unless one also accomplished that same cultural migration. In this way, the Confessions assembled and composed, rather than merely

\footnotetext{
${ }^{169}$ Confessions X.4.6 (credentium filiorum hominum, sociorum gaudii mei et consortium mortalitatis meae).

${ }^{170}$ Frances Young, "The Confessions of St. Augustine: What is the Genre of this Work?," Augustinian Studies 30 (1999), 13.

171 Pope John Paul II, “'A'Augustinum Hipponensem," I. See also Brian Stock, "Ethics and the Humanities: Some Lessons of Historical Experience," New Literary History 36 (2005), 15.
} 
addressed, its immediate audience. In some ways, our age offers a similar challenge for Augustine's text. The historical significance of Augustine as the "common father of Christian Europe," ${ }^{172}$ has meant that some readers are content to investigate the Confessions from an antiquarian, philosophical, or literary perspective. But even for those willing to see the enduring religious significance of this work, the greater challenge may emerge from the post-modern condition. ${ }^{173}$ In the fragmented culture of the post-modern West, it is more difficult for readers to answer Augustine's invitation and to take his pastoral direction seriously. They may not see themselves as among those called by Augustine's pastoral rhetoric. And, while there are still an exceptional few who study late antiquity or the early Middle Ages, most twenty-first century readers lack many of the common cultural resources (especially Scriptural literacy) that enables Augustine's writing to fully resonate in their lives. As it did in its own day, then, the Confessions proposes for us an alternative sensibility to the prevailing worldly culture. Still, when we understand that nothing in the Confessions is so uniquely personal, or so doctrinally archaic as to be irrelevant to us, we can see that the audience for the Confessions is continually coming into being.

Understanding the Confessions as a pastoral work addressed to all Christians, even to those who, in Augustine's imagination, "are still to come," reminds us that the text is alive, that it continually summons a new audience into the sphere of its influence. In this way, the text is remarkable as an example of rhetoric that refashions its ideal audience among the Christian believers and theological searchers of each generation. Augustine speaks to "every man whose soul is tethered by the love of things that cannot

\footnotetext{
172 Pope John Paul II, "Augustinum Hipponensem," II.

173 On this point, see Michael Calvin McGee, "Text, Context, and the Fragmentation of Contemporary Culture," Western Journal of Speech Communication 54 (1990), 274-289.
} 
last." ${ }^{174}$ The text calls sinners to repentance, and gathers a community set apart by the sincerity of their Christian commitment. Augustine asks God about his readers: "Is it that they wish to join with me in thanking you, when they hear how close I have come to you by your grace, and to pray for me, when they hear how far I am set apart from you by the burden of my sins? If this is what they wish, I shall tell them what I am. For no small good is gained."175 Augustine's invitation, then, is renewed for every reader. For those who understand that Augustine speaks to them pastorally, for those willing to respond to the sacramental character of the Confessions, Augustine's rhetoric is still at work.

\section{B. What is the rhetorical message of the text?}

Well, what does Augustine say to us? If we imagine ourselves as among those whom Augustine addresses with his pastoral concern, how are we to read the Confessions? It is a question Augustine himself poses in Book X: "Why, then, does it matter to me whether men should hear what I have to confess?" he asks. ${ }^{176}$ "What good do they hope will be done if they listen to what I say? ${ }^{n 177}$ We recognize that the main action of the text is self-disclosure. However, it is not disclosure for its own sake. Augustine is not interested in satisfying the idle curiosity of strangers. His purpose is pastoral, and his writing is a "sacrifice." ${ }^{178}$ As he had directed homilists in De Doctrina Christiana, his own writing is aimed at "those on whose account we speak." 179 It is a

\footnotetext{
${ }^{174}$ Confessions IV.6 (et miser est omnis animus vinctus amicitia rerum mortalium).

${ }^{175}$ Confessions X.4.5 (an congratulari mihi cupiunt, cum audierint quantum ad te accedam munere tuo, et orare pro me, cum audierint quantum retarder pondere meo? indicabo me talibus. non enim parvus est fructus).

${ }_{177}^{176}$ Confessions X.3.3 (quid mihi ergo est cum hominibus, ut audiant confessiones meas).

177 Confessions X.4.5 (sed quo fructu id volunt).

${ }_{178}$ Confessions V.1.1 (accipe sacrificium confessionum mearum de manu linguae meae). See also XI.2.3

${ }^{179}$ De Doctrina Christiana IV.10.24 (propter quos ut intellegant loquimur).
} 
lesson "useful to the building of charity," ${ }^{180}$ and undertaken for the purpose of "bringing the truth which we have perceived, no matter how difficult it may be to comprehend or how much labor may be involved, to the understanding of others." ${ }^{\text {181 }}$ Augustine's rhetoric in the Confessions, then, motivated by charity and pastoral duty, is not merely an act of self-disclosure. It is the profoundly Christian rhetoric of self-donation. Judged by worldly standards, the revelations of the Confessions are often humiliating to the author. But, judged as pastoral rhetoric, the full confession of his sins is instructive. In De Doctrina Christiana Augustine writes about interpreting the accounts of sinful behavior by good men in the Old Testament. If a reader contemplates "the sins of great men," he may "put the nature of the things done to this use, that he will never hear himself boast of his own virtuous deeds and condemn others from the vantage of his righteousness when he sees in such men the tempests that are to be shunned and the shipwrecks that are to be lamented." ${ }^{182}$ Thus by recounting his own great sins, by giving his life fully to his readers, Augustine fulfills a pastoral duty, shows his own powerlessness over sin, and consequently humbly acknowledges God's saving action in his life. "What evil have I not done? Or if there is evil that I have not done, what evil is there that I have not spoken?" he asks rhetorically. Still, it was God who "saw how deep I was sunk in death," and who "drained dry the well

\footnotetext{
${ }^{180}$ De Doctrina Christiana I.36.40 (ut huic aedificandae caritati sit utilis).

${ }^{181}$ De Doctrina Christiana IV.9.23 (ut vera quamvis ad intellegendum difficillima, quae ipsi iam percepimus, cum quantocumque labore disputationis ad aliorum intellegentiam perducamus). ${ }^{182}$ De Doctrina Christiana III.23.33 (peccata magnorum virorum ... animadvertere atque indagare potuerit, rei tamen gestae proprietatem ad hunc usum assumat, ut se nequaquam recte factis suis iactare audeat et prae sua iustitia ceteros tamquam peccatores contemnat, cum videat tantorum virorum et cavendas tempestates, et flenda naufragia). See also Confessions III.7.13.
} 
of corruption" in Augustine's heart. ${ }^{183}$ It is Augustine's story, but the agent of conversion is always God. "As my misery grew worse," Augustine addressed God, "you came the closer to me. Though I did not know it, your hand was poised ready to lift me from the mire and wash me clean." ${ }^{184}$

Throughout De Doctrina Christiana, Augustine is concerned with the interpretation of "signs," a way of understanding the hidden meanings in a scriptural text, and of conveying that meaning in instruction to fellow Christians. With this principle in mind, we can also see the Confessions as both Augustine's recognition of God's sacramental work in his life, and Augustine's communication of those "signs" to his readers. In Augustine's theory of communication, a "sign is a thing which causes us to think of something beyond the impression the thing itself makes upon the senses." 185 From our early catechism lessons, we recall that a sacrament is "an outward sign, instituted by Jesus Christ, by which inward grace is given to us." ${ }^{\text {186 }}$ The Confessions is sacramental, then, insofar as it offers a sign of the Christian grace in Augustine's life, and yet also points the reader to something beyond this individual life as the source of that grace. To judge from his own statement of motive, this would seem to be exactly the purpose Augustine had in mind. "If my pen is my spokesman," he writes, addressing God in Book XI, "when shall I be able to tell of all the means you used to 183 Confessions IX.1.1 (quid non mali aut facta mea aut, si non facta, dicta mea aut, ... tu autem, domine,
bonus et misericors, et dextera tua respiciens profunditatem mortis meae et a fundo cordis mei
exhauriens abyssum corruptionis.).
${ }^{84}$ Confessions (VI.16 (ego fiebam miserior et tu propinquior. aderat iam iamque dextera tua raptura me
de caeno et ablutura, et ignorabam).
${ }^{185}$ De Doctrina Christiana II.1.1 (signum est enim res, praeter speciem quam ingerit sensibus).
${ }^{186}$ Rev. Joseph Deharbe, S. J., Catechism of Christian Doctrine (New York: Fr. Pustet, Co., 1901), 81.
Augustine himself makes this connection in De Doctrina Christiana (III.9.13) when he describes the
Christian who "uses or venerates a useful sign divinely instituted whose signifying force he understands
does not venerate what he sees and what passes away but rather that to which all such things are to be
referred" (Qui vero aut operatur aut veneratur utile signum divinitus institutum, cuius vim
significationemque intellegit, non hoc veneratur quod videtur et transit, sed illud potius quo talia cuncta
referenda sunt). See also Mazzeo, 179-183. 
make of me a preacher of your word and a minister of your sacrament to your people?"187

Throughout this sacramental act of self-donation, Augustine keeps his audience and his pastoral duty in mind. "When they hear what I have to tell," he writes, "all who adore you will exclaim, 'Blessed be the Lord in heaven and on earth. Great and wonderful is his name." ${ }^{188}$ His work, then, gives the reason for men and women, then and now, to "rejoice more for the salvation of a soul for which all had despaired, or one that is delivered from great danger." ${ }^{189}$ But just as he writes with our good, our eternal salvation, in mind, Augustine also depends on the charity of the reader. "How do they know whether I am telling the truth?"190 he asks. "But charity believes all things -- all things, that is, which are spoken by those who are joined as one in charity -- and for this reason I too, O Lord, make my confession aloud in the hearing of men."191 He writes to those who, "whether they see good in me or evil, they love me still. To such as these I shall reveal what I am." ${ }^{192}$ In this way, too, Augustine contributes directly to his further persuasive work as a pastor of souls. In De Doctrina Christiana, Augustine tells his clerical homilists that "the life of the speaker has greater weight in determining whether he is obediently heard than any grandness of eloquence." ${ }^{193}$ He warns against

\footnotetext{
${ }^{187}$ Confessions XI.2.2 (quando autem sufficio lingua calami enuntiare omnia hortamenta tua et omnes terrores tuos, et consolationes et gubernationes, quibus me perduxisti praedicare verbum et sacramentum tuum dispensare populo tuo).

${ }^{188}$ Confessions VIII.1.1 (narrabo, et dicent omnes qui adorant te, cum audiunt haec, 'benedictus dominus in caelo et in terra; magnum et mirabile nomen eius. ).

${ }^{189}$ Confessions VIII.3.6 (quid agitur in homine, ut plus gaudeat de salute desperatae animae et de maiore periculo liberatae).

${ }_{190}$ Confessions X.3.3 (et unde sciunt, cum a me ipso de me ipso audiunt, an verum dicam).

${ }^{191}$ Confessions X.3 (sed quia caritas omnia credit, inter eos utique quos conexos sibimet unum facit, ego quoque, domine, etiam sic tibi confiteor ut audiant homines).

${ }^{192}$ Confessions X.4.5 (quia sive approbet sive improbet me, diligit me. indicabo me talibus).

${ }^{193}$ De Doctrina Christiana IV.27.59. (habet autem ut oboedienter audiatur quantacumque granditate dictionis maius pondus vita dicentis).
} 
hypocrisy, and advises his priests and deacons that "many more would be benefited if [homilists] were to do what they say."194

As the story of Augustine's life in the care of God, the Confessions serves as the foundation for his pastoral ethos. But the work is more than a persuasive resource; it also embodies Augustine's new rhetoric. Indeed, the whole gesture of Augustine's sacramental self-donation is an enactment of the ethical principles of his new Christian rhetoric. If the De Doctrina Christiana is the theoretical statement of those principles, the Confessions is the embodied performance of those same commitments as well as the evidence of their efficacy. The Christian reader, the "true brother" of Augustine, is left only to accept the gift of his self-donation, and apply the lesson from his reading to his own life. ${ }^{195}$

\section{How shall we respond to the work?}

In De Doctrina Christiana, Augustine borrows from Cicero and tells us that "he who is eloquent should speak in such a way that he teaches, delights, and moves."196 The most important of these, however, is the last. "The truth of what is said is acknowledged in vain and the eloquence of the discourse pleases in vain unless that which is learned is implemented in action," he writes. ${ }^{197}$ The action of which Augustine speaks is repentance and conversion, it is the action he enacts in the narrative of the Confessions. "I did not think I had done anything when I heard them applauding," he

\footnotetext{
${ }^{194}$ De Doctrina Christiana IV.27.60 (pluribus prodessent faciendo quae dicunt). On this point, see also Seibach, 98.

${ }_{195}$ Brian Stock made a similar point when he observed that audiences in Augustine's time "directed their thinking about postreading experiences less toward the meaning of the text itself than toward the meaning for themselves." ("Ethics and the Humanities," 15).

${ }_{196}^{196}$ De Doctrina Christiana IV.12.27 (ita dicere debere eloquentem ut doceat, ut delectet, ut flectat).

${ }^{197}$ De Doctrina Christiana IV.13.29 (Cum vero id docetur quod agendum est, et ideo docetur ut agatur, frustra persuadetur verum esse quod dicitur, frustra placet modus ipse quo dicitur, si non ita discitur ut agatur).
} 
remarks concerning those in his congregation, "but when I saw them weeping." ${ }^{\text {"198 }}$ The effect of rhetoric is to be seen, not in the approval of his parishioners, "but rather through their groans, sometimes even through tears, and finally through a change of their way of life." ${ }^{199}$

Scholars of Augustine have explored the Confessions for its theological, philosophical, psychological, historical, and biographical significance. And, a text as rich as the Confessions will continue to yield significant insights into both its author and the human condition. Yet, I would propose that if we want to take the Confessions on its own terms, the only appropriate response - that is, the response invited by the Christian rhetoric at work in the text - is to take the question of our own conversion seriously. Augustine has offered us a sacramental rhetoric. The Confessions is a written text that signifies to us the grace that God offers each sinner. Augustine's work is one of self-donation, composed in truth, and crafted with pastoral charity. Such a work positions the reader as a potential member of Augustine's extended Christian community. To respond to Augustine's rhetoric is to join that community. Seen in the light of Augustine's own theoretical work on rhetoric, there is only one response to that invitation that serves to encompass both his contemporary readers, and us. It is the only response that is consistent with the summons of the text itself. It is the Christian response, a response not to Augustine but to God.

\footnotetext{
${ }^{198}$ De Doctrina Christiana IV.24.53 (non tamen egisse aliquid me putavi, cum eos audirem acclamantes, sed cum flentes viderem).

${ }^{199}$ De Doctrina Christiana IV.24.53 (non clamore potius quam gemitu, aliquando etiam lacrimis, postremo vitae mutatione monstrasse).
} 